\title{
MAO AND XI: STORY OF THE
MAN, STORY OF THE PEOPLE Bryce Kositz
}

I

S XI JINPING the new Chairman Mao? Now that the Chinese Communist Party (CCP) has eliminated the two-term limit for the leader of the People's Republic of China, there's nothing to stop $\mathrm{Xi}$ from serving as leader-for-life - despite official denials that he intends to do so. Like Mao Zedong, Xi has carefully crafted a narrative of his personal history to legitimise his power and policies. Both Mao and Xi built a story, or mythos, about their lives that positioned themselves as the representative of the nation as a whole, with their personal struggles being depicted as identical to those of China.

Mao told his version of his story to American journalist Edgar Snow, who published his account, Red Star Over China, in 1937. As he described it to Snow, each period of his life followed

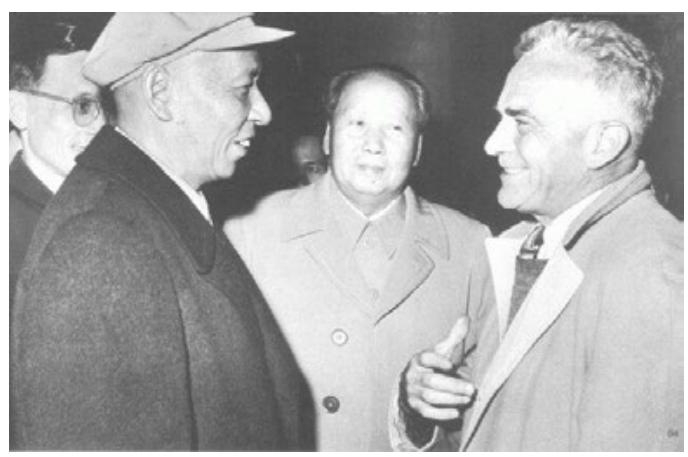

Liu Shaoqi (L), Mao Zedong (C), and Edgar Snow (R), 1960

Source: Wikipedia 
a similar pattern: Mao recognised right from wrong and was punished for pointing it out, but after gathering allies to fight with him, he and his ideas eventually emerged victorious. Mao's narrative of his life story reflected China's struggle for independence from the foreign powers that had established their power over it since the 1839-42 Opium War. He struggled with his highly traditional father to educate himself in new, Western topics including Marxism. He persevered and struggled with enemies outside the Party and rivals within it, until he won the right to lead the CCP, which was fighting against both the Japanese and Chiang Kai-shek's Nationalist government. His personal struggle embodied that of the Party; Mao's victory was that of the Party - and China itself.

The son of Mao's comrade Xi Zhongxun, Xi Jinping was sent to work in the rural area of Liangjiahe in Shaanxi during the Cultural Revolution before eventually climbing the ranks to become General Secretary of the CCP in 2012. His preferred narrative is that of the 'man of the people' who achieved power and prominence while remaining grounded in the realities of China's least privileged citizens. It can be summed up by the closing sentence of a short, autobio-

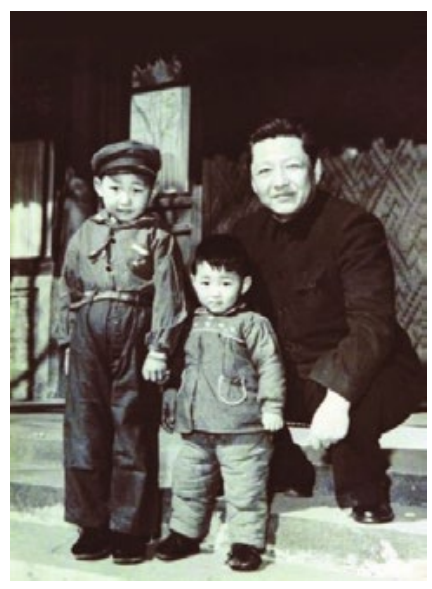

'Son of the loess lands': Five-year-old Xi Jinping (L) with his younger brother, $\mathrm{Xi}$ Yuanping, and father, $\mathrm{Xi}$ Zhongxun, 1958

Source: Wikipedia

graphical work: 'No matter where I go, I will always be a son of the loess lands 黄土地'. ${ }^{1}$ Similarly, he described his work as provincial governor in Zhejiang by saying, 'I have seen nearly all of Zhejiang's mountains and waters ... and personally experienced the state and characteristics of Zhejiang and all its counties'. ${ }^{2}$ Xi presents himself as China's son, revolutionary by birth, humble by experience, and rising to power through hard work: a mirror of China's progress over his lifetime. During his first visit to the US as General Secretary, Xi even returned to a town in Iowa that he had visited during an agricultural survey in 1985 to reconnect with 'old friends'. ${ }^{3}$ So, not only is he connected to all the Chinese people, 
Xi also has friends abroad - an important point for an outward-looking China. These friends in Iowa, moreover, reinforce Xi's story about remaining grounded in the struggles of the least privileged, even as China asserts itself globally.

Both Mao and Xi spoke sparingly about their personal histories and only during the early years of their political career, thereafter letting their allies elaborate on their stories for them. of his interview with Mao, Edgar Snow remarked that, 'During Mao's recollections of his past I noticed that an auditor at least as interested as myself was Ho Tze-nien [He Zizhen] — his wife. Many of the facts he told about himself and the Communist movement she had evidently never heard before'. ${ }^{4}$ Snow's interview of Mao is one of the only records of Mao discussing his personal life. Xi, likewise, has spoken little about his life and only during the early years of his political career, largely in the single-page autobiographical work, written in 1998, quoted above.

Most importantly, Xi Jinping and Mao Zedong both used their personal stories to define the story of China for their times, legitimise their policies, and control political discourse. As seen through the prism of the official narrative, Mao's personal struggle for recog- nition within the CCP stood in for the history of China from the beginning of its loss of national independence in the 1840 Opium War; the story of all Chinese history since 1840 condensed down into the story of one man - Mao. Mao thus predicted that, just as he had gained control of CCP to fix the problems within the Party, so would his power within China solve its national problems. This legitimised his power over the Party and explained the necessity of his policies of resistance and collectivisation.

Xi's story about rising through the ranks of the Party while remaining in touch with all levels of society similarly projects a narrative of China's retention of its revolutionary ideals after 1949. The story portrays Xi, and the Chinese nation as, having learned the revolutionary morality of the Mao era, using these inherited values to guide the modern economy - thus the importance of his campaign against corruption, for example. Xi, moreover, likens his own rise to personal power within the Party to his plans for China to rise in prominence and power on the world stage, ensuring that all its people can attain the China dream in the process. Like Mao Zedong, if he has to take a lifetime to achieve these national goals, he will. 
This text is taken from China Story Yearbook 2018: Power, edited by Jane Golley, Linda Jaivin, Paul J. Farrelly and Sharon Strange, published 2019 by ANU Press, The Australian National University, Canberra, Australia.

doi.org/10.22459/CSY.2019.00B 